\title{
STUDI KUALITAS DAN KUANTITAS AIR BERSIH PADA GERBONG KERETA API STASIUN PURWOKERTO
}

\author{
Ena Trisiyani Dewi ${ }^{1)}$, Tri Marthy Mulyasari ${ }^{1)}$ \\ 1) Poltekkes Kemenkes Semarang
}

\begin{abstract}
Abstrak
Air bersih pada gerbong kereta api digunakan untuk kamar mandi pada setiap gerbong. Air bersih pada kereta api berperan penting bagi penumpangnya, apabila air bersih yang digunakan kualitasnya tidak sesuai dengan peraturan, maka dapat berdampak bagi pengguna air bersih tersebut. Desain penelitian yang digunakan adalah deskriptif. Pengumpulan data dengan pengamatan, wawancara, dan pemeriksaan. Data ini disajikan dengan menggunakan editing, coding, tabulating dan saving. Hasil penelitian pada kereta api ekonomi yaitu kualitas fisik, kimia, dan mikrobiologi telah memenuhi standar Permenkes 32 Tahun 2019, dengan hasil tidak berbau, tidak berasa, pemeriksaan warna 10,7 TCU, kekeruhan $<5 \mathrm{NTU}$, TDS $258 \mathrm{mg} / \mathrm{l}$, suhu $29^{\circ} \mathrm{C}$, pH 8 , dan total coliform $41 \mathrm{CFU} / 100 \mathrm{ml}$. Keadaan sarana sanitasi pada kereta api ekonomi kurang baik, dengan reservoir sudah berkarat, dan toilet yang berbau urine. Air bersih pada kereta api eksekutif yaitu kualitas fisik, kimia, dan mikrobiologi telah memenuhi standar Permenkes 32 Tahun 2019 yang meliputi hasil air tidak berbau, tidak berasa, warna air 5,5 TCU, kekeruhan $<5 \mathrm{NTU}$, TDS $353 \mathrm{mg} / \mathrm{l}$, suhu $24^{\circ} \mathrm{C}$, pH 8,4, dan total coliform $23 \mathrm{CFU} / 100 \mathrm{ml}$. Keadaan sarana sanitasi pada kereta api eksekutif kurang baik terdapat pada reservoir yang berkarat. Pada kedua kereta kondisi sarana perpipaan sudah baik. Kuantitas pada kereta api ekonomi tidak memenuhi syarat yaitu hanya dapat memenuhi kebutuhan air bersih sebanyak 166 orang, yang seharusnya 212 orang, sedangkan untuk kereta api eksekutif kuantitas air telah memenuhi syarat. Kesimpulan penelitian ini adalah kualitas dan kuantitas air bersih sudah memenuhi syarat dengan kondisi baik. Keadaan sanitasi dari reservoir gerbong kereta tidak memenuhi syarat dan keadaan sanitasi toilet tidak memenuhi syarat untuk kereta api ekonomi. Saran peneliti pada PT. KAI yaitu melakukan pemeliharaan terhadap reservoir dengan melakukan pengurasan dan pembilasan secara rutin. Serta memelihara jaringanjaringan perpipaan air bersih.
\end{abstract}

Kata Kunci: Total Coliform, Air Bersih, Kereta Api

\begin{abstract}
[Title: The Quality and Quantity of Sanitation Water Carriage Train of Purwokerto Station 2019]

Sanitation water in train is used for bathrooms on each carriage. Clean water on trains is important for passengers, if the clean water used is not in accordance with the regulations, it can have an impact on the users of clean water. The method used is descriptive. Data collection with observations, interviews, and examinations. Processing data using editing, coding, tabulating and saving. The results of the research on economic trains are physical, chemical, and microbiological qualities that have met the standards of Minister of Health Regulation 32 of 2019, with odorless, tasteless, color checks $10.7 \mathrm{TCU}$, turbidity $<5 \mathrm{NTU}$, TDS $258 \mathrm{mg} /$ l, temperature $29^{\circ} \mathrm{C}, \mathrm{pH} 8$, and total coliform 4lCFU / 100ml. The condition of sanitation facilities on the economic train is not good, with the reservoir already rusty, and the toilet that smells of urine. Then the results of executive train research are physical, chemical, and microbiological quality that have met the Minister of Health Regulation 32 of 2019 which includes odorless, tasteless water, 5.5 TCU water color, turbidity $<5$ NTU, TDS $353 \mathrm{mg} / \mathrm{l}$, temperature $24^{\circ} \mathrm{C}, \mathrm{pH} \mathrm{8.4}$, and total coliform $23 \mathrm{CFU} / 100 \mathrm{ml}$. The condition of the sanitation facilities on the executive railroad is not good in the rusty reservoir. On both trains the condition of the piping facilities is good. The conclusion of this study is that the quality and quantity of sanitation water has met the conditions with good conditions. The sanitation situation of the train carriage reservoir does not meet the conditions and conditions of toilet sanitation which do not qualify for the economic train. Suggestions from researchers at PT. KAI is carrying out maintenance of the reservoir by routinely draining and rinsing. And maintain clean water piping networks
\end{abstract}

Keywords: Total Coliform, Sanitation Water, Train 


\section{Pendahuluan}

Air merupakan kebutuhan sehari - hari manusia, baik untuk dikonsumsi, sebagai sarana sanitasi dan lainnya, maka air diharuskan ada pada setiap tempat dimana manusia berada. Salah satu tempat dimana selalu dikunjungi atau digunakan manusia adalah transportasi. Menurut Salim (2000) transportasi adalah kegiatan pemindahan barang (muatan) dan penumpang dari suatu tempat ke tempat yang lain. Pada trasnportasi ini air sangat berperan penting. Baik untuk media perjalanan, sebagai salah satu komponen pembangkitnya, ataupun sebagai sarana penunjang fasilitas penumpang pada transportasi.

Kereta Api Daop V Purwokerto merupakan kantor yang mengurusi pengoperasian kereta api yang berada di Purwokerto, Kabupaten Banyumas dan sekitarnya. Banyumas sendiri memiliki satu stasiun kereta api yaitu Stasiun Kereta Api Purwokerto. Sebagian besar masyarakat Purwokerto menggunakan transportasi kereta api untuk bepergian baik luar kota maupun luar provinsi. Purwokerto merupakan kota yang memiliki beberapa perguruan tinggi dan lapangan pekerjaan yang berpotensi menjadikan kota Purwokerto semakin padat penduduk sehingga frekuensi penggunaan transportasi kereta api akan semakin besar.

Air bersih pada gerbong kereta api digunakan untuk kamar mandi pada setiap gerbong. Air bersih pada kereta api berperan penting bagi penumpangnya, apabila air bersih yang digunakan kualitasnya tidak sesuai dengan peraturan , maka dapat berdampak bagi pengguna air bersih tersebut.

Air bersih pada Stasiun Kereta Api Purwokerto salah satunya bersumber dari sumur gali yang berada di Depo Kereta Api Purwokerto. Air bersih pada sumur ini salah satunya digunakan untuk mengisi tangki air yang ada pada kereta api untuk dialirkan dengan pipa ke kamar mandi tiap gerbong kereta api. Stasiun Kereta Api Purwokerto telah rutin melakukan pengawasan kualitas air bersih pada Depo Kereta Api yang dilaksanakan oleh Balai Laboratorium Kesehatan Yogyakarta selama enam bulan sekali. Pada pengukuran kualitas air bersih, air sumur Depo Kereta Api Purwokerto tahun 2018 pada parameter mikrobiologi (MPN Coliform) didapati hasil sebesar 33 MPN/100ml. Pengambilan sampel tersebut diambil pada kran air yang bersumber dari sumur. Pada pengukuran tersebut masih menggunakan acuan Peraturan Menteri Kesehatan Nomor 416 Tahun 1990 Tentang Syarat - Syarat dan Pengawasan Kualitas Air yang memiliki baku mutu sebesar $10 \mathrm{MPN} / 100 \mathrm{ml}$ untuk air perpipaan, sehingga air tersebut tidak memenuhi syarat. Apabila sumber air bersih yang digunakan untuk penumpang kereta api sudah tidak memenuhi standar, maka dapat berpengaruh pada kesehatan penumpang.

\section{Bahan dan Metode}

Penelitian ini termasuk jenis penelitian deskriptif dengan tujuan memperoleh gambaran mengenai kualitas mikrobiologi air bersih di gerbong kereta api. Waktu dalam penelitian dilakukan dalam hari 4 hari yaitu pada tanggal 2 April - 29 April 2019.

Cara pengumpulan data dengan observasi, wawancara, dan pengukuran kualitas air parameter fisik, kimia dan mikrobiologi. Desain penelitian yang digunakan dalam penelitian ini adalah deskriptif, dengan tujuan untuk mendeskripsikan kualitas dan kuantitas air bersih pada gerbong kereta api Stasiun Purwokerto Tahun 2019.

Analisis yang digunakan dalam penelitian adalah deskriptif dengan menguraikan hasil pengamatan yang disajikan dalam bentuk data.

\section{Hasil dan Pembahasan}

a. Stasiun Kereta Api Purwokerto

Stasiun Kereta Api Purwokerto berada di wilayah Kecamatan Purwokerto Barat Kabupaten Banyumas. Adapun batas-batas wilayah Stasiun Kereta Api Purwokerto adalah sebagai berikut :

Sebelah Selatan :Kelurahan Bantarsoka

Sebelah Barat : Kelurahan Rejasari

Sebelah Utara : Kelurahan Kober

Sebelah Timur : Kelurahan Kober

Luas wilayah Stasiun Kereta Api Purwokerto yaitu sekitar 1.500m3. ketinggian Stasiun Kereta Api Purwokerto 75 meter di atas permukaan air laut.

\section{b. Kereta Api}

Kereta Api Kamandaka merupakan Kereta Api Penumpang kelas Eksekutif dan Ekonomi AC Plus milik PT. Kereta Api Indonesia (Persero) yang melayani jalur kereta ap Purwokerto-Semarang Tawang maupun sebaliknya.

Pada satu rangkaian kereta ini terdapat 7 gerbong penumpang, diantaranya 3 gerbong Ekonomi AC Plus, 3 Gerbong Eksekutif, dan 1 gerbong restorasi. Pengaturan tempat duduk untuk gerbong kereta api Kamandaka Eksekutif yaitu 50 tempat duduk, disusun 2-2, reclining and revolving seat. Gerbong Kereta Api Kelas Ekonomi AC Plus, 64 tempat duduk disusun 2-2, recling and revolving seat (khusus untuk difabel), saling berhadapan ke kiri dan ke kanan atau 80 tempat duduk disusun 2-2, saling berhadapan ke kiri dan ke kanan.

Berdasarkan observasi pada gerbong kereta ini, kondisi rangkaian kereta api dalam keadaan bersih dan rapi. Tidak ditemui sampah yang berserakan. Konstruksi yang masih baik dan tidak dijumpai perkaratan pada rangkaian. Satu rangkaian kereta ini berjumlah 6 gerbong dengan 106 kursi penumpang per gerbongnya. Sirkulasi udara yang digunakan pada kereta ini yaitu AC dengan jumlah 6 buah AC per gerbong yang diletakkan di atas bagian tengah gerbong. Pencahayaan yang digunakan adalah lampu LED. Pada satu gerbong terdapat 2 toilet yang 
terletak di pada setiap ujung gerbong. Toilet dilengkapi dengan closet duduk, flushing, wastafel, tisu, kaca dan tong sampah.

\section{c. Kelas Ekonomi Serayu}

Kereta Api Serayu merupakan kereta api penumpang kelas Ekonomi AC yang dioperasikan oleh PT. Kereta Api Indonesia (Persero) Daerah Operasi V Purwokerto yang melayani rute Purwokerto-Pasar Senen via Kroya/Kiaracondong dan sebaliknya.

Berdasarkan observasi, kondisi gerbong ini bersih, tidak dijumpai sampah berserakan. Konstruksi rangkaian kereta masih baik dengan tidak dijumpai perkaratan pada rangkaian. Rangkaian kereta ini menggunakan AC central sebagai sirkulasi udaranya. Dalam satu gerbong terdapat 50 kursi penumpang. Pencahayaan yang digunakan adalah lampu berjenis LED. Satu gerbong terdiri satu toilet yang dilengkapi dengan closet duduk, flushing, wastafel, tisu , kaca, dan tong sampah.

\section{d. Sumber Dan Pendistribusian Air Bersih Di Gerbong Kereta Api}

Air bersih yang digunakan untuk gerbong kereta api di Stasiun Purwokerto bersumber dari sumur artesis dengan luas area sumur artesis sebesar $20 \mathrm{~m} 2$, kedalaman sumur artesis sebesar 150 meter dan ketinggian dinding bak penampungan sebesar 3 meter

Air bersih yang berasal dari sumur tersebut juga digunakan untuk air yang berada di gerbong kereta. Pengisian air bersih tersebut dilakukan dengan cara mengalirkan air bersih dari sumur dengan pompa air melalui pipa GI, yang kemudian didistribusikan ke kran kran melalui pipa PVC. Pengisian air bersih pada gerbong dilakukan dengan mengalirkan air dengan selang ke lubang reservoir gerbong kereta yang berada di atas gerbong dari kran yang berada di pinggir track pencucian gerbong.

e. Keadaan Sanitasi Sarana Air Bersih Kereta Api

1) Reservoir Air Bersih Gerbong

Tabel 1. Keadaan Sanitasi Reservoir Air Bersih Gerbong Kereta Api Kelas Ekonomi Eksekutif

\begin{tabular}{lllll}
\hline No & Kereta Api & Kelas & Hasil(\%) & Keteranganl \\
\hline 1. & Serayı & Ekonomi & $\measuredangle 100 \%$ & Tidak Baik \\
\hline 2. & Kamandaka & Eksekutif & $\ll 100 \%$ & Tidak Baik
\end{tabular}

Berdasarkan hasil observasi yang telah dilaksanakan pada tanggal 2 April hingga 25 April 2019 dapat digambarkan bahwa keadaan sanitasi reservoir Kereta Api Kelas Ekonomi yaitu Serayu, tidak baik dengan skor $>100 \%$. Salah satu faktor yang tidak memenuhi syarat adalah konstruksi reservoir yang sudah tua dan berkarat atau mengalami korosi dan beberapa bagian permukaan telah mengelupas. Konstruksi pada reservoir gerbong ini terbuat dari stainless steel dengan kapasitas air sebesar 500liter.

Reservoir ini memiliki satu lubang dengan diameter kurang lebih $20 \mathrm{~cm}$. Lubang ini digunakan untuk pengisian air bersih melalui selang. Lubang ini dilengkapi dengan penutup. Tidak ada perlakuan khusus untuk reservoir. Tidak dilakukannya pengurasan dan tidak dilakukannya klorinasi. Hal ini dapat mempengaruhi kualitas air bersih yang tersimpan didalamnya.

Kereta Api kelas eksekutif yang pemberhentian terakhirnya di Stasiun Purwokerto adalah Kereta Api Kamandaka. Pada rangkaian kereta api ini, terdapat dua kelas kereta dalam satu rangkaian, yaitu 4 gerbong kereta kelas ekonomi dan 3 gerbong kereta kelas eksekutif. Kereta ini memiliki satu buah reservoir dalam satu gerbong dengan kapasitas 1000liter. Berdasarkan hasil observasi yang telah dilakukan, reservoir kereta ini memiliki keadaan sanitasi yang tidak baik, dimana lubang resevoir sudah korosi. Konstruksi reservoir ini dibuat dari bahan stainless steel.

2) Keadaan Sanitasi Perpipaan Air Bersih Kereta Api

Berdasarkan hasil observasi yang telah dilakukan, pendistribusian air bersih pada kereta api bersumber dari sumur artesis. Air bersih dipompa dan disalirkan dengan pipa galvanis yang kemudian ditampung didalam bak penampungan dengan ketinggian 3 meter. Kemudian air yang didalam bak penampung dialirkan menuju kran kran konsumen. Perpipaan dari sumber air ke kran tidak bocor dan aliran lancar. Pemeriksaan perpipaan dilakukan secara insidentil apabila terjadi kendala pada aliran perpipaan. Tidak ada perkaratan pada pipa distribusi dikarenakan menggunakan pipa pvc. Untuk perpipaan air bersih pada gerbong kereta api dialirkan dengan metode gravitasi dengan menggunakan pipa PVC. 
3) Keadaan Kebersihan Toilet

Tabel 2. Keadaan Sanitasi Toilet Air Bersih Gerbong Kereta Api Kelas Ekonomi Eksekutif

\begin{tabular}{llllll}
\hline No & KeretaApi & Kelas & $\begin{array}{l}\text { Jumlah toilet } \\
\text { per gerbong }\end{array}$ & Hasil(\%) & Keterangan \\
\hline 1. & Serayu & Ekonomi & 2 & $\measuredangle 100 \%$ & TidakBaik \\
\hline 2. & Kamandaka & Eksekutif & 1 & $100 \%$ & Baik \\
\hline
\end{tabular}

Berdasarkan hasil observasi, kereta api kelas ekonomi yaitu Kereta Api Serayu didapati hasil inspeksi dengan skor $<100 \%$. Hal ini disebabkan toilet pada gerbong kereta tersebut berbau urine.

Berdasarkan hasil observasi, kereta api kelas eksekutif yaitu Kereta Api Kamandaka didapati hasil $100 \%$. Kondisi toilet yang bersih, tidak berbau urine dan terbebas dari sampah. Toilet yang bersih dapat mencegah timbulnya sarang vektor, seperti kecoa. Apabila terdapat kecoa didalam toilet, maka dapat menularkan penyakit atau disebut dengan water related vector mechanism. Serangga ini bersifat potensial sebagai penular saluran pencernaan yang disebabkan bakteri, protozoa, dan virus. Berdasarkan isolasi terhadap mikroorganisme pada kecoa, terdapat 4 strain virus poliomielitis serta 40 spesies bakteri patogen, terutama dari Enterobacteriaceae termasuk Laprosybacterium dan Entamuba hystolitica (Terang Uli J. Sembiring \& Dewi Susanna,2011).

4) Pemberantasan Vektor Pada Gerbong Kereta Api

Berdasarkan wawancara yang telah dilakukan, pengendalian vektor yang telah dilakukan oleh petugas Kereta Api Stasiun Purwokerto, yaitu pihak Stasiun Purwokerto bekerja sama dengan pihak ketiga yang menangani dalam bidang pemberantasan vektor. Pengendalian vektor yang dilakukan di gerbong kereta biasanya dilakukan dengan cara pengasapan atau biasa disebut fumigasi.

Fumigasi ini dilakukan dua kali dalam satu bulanya. Selain itu juga memberikan rodent bite dengan memberikan racun terhadap makanan yang ditaruh ditempat-tempat keberadaan vektor dan juga penyemprotan untuk membasmi vektor yang ada digerbong kereta api. Pembersihan tempat duduk penumpang juga rutin dilakukan agar tetap bersih dan memberikan kenyamanan pada penumpang.
5) Kualitas Air Fisik Bersih Gerbong Kereta Api

Tabel 3. Pemeriksaan Bau Air Pada Gerbong Kereta Api

\begin{tabular}{lllll}
\hline No & Kereta Api & Kelas & Hasil $(\%)$ & Keterangan \\
\hline 1. & Serayu & Ekonomi & $<100 \%$ & Tidak Baik \\
\hline 2. & Kamandaka & Ekselkutif & $<100 \%$ & Tidak Baik
\end{tabular}

Berdasarkan dari pemeriksaan bau air pada gerbong kereta api dengan 3 orang pembau, dikatahui hasil dari kedua kereta api tidak memiliki bau. Bau pada air berpengaruh pada estetika. Bau pada air juga dapat disebabkan oleh beberapa faktor seperti bau amis pada air yang dapat disebabkan karena faktor bakteri dan kadar $\mathrm{H} 2 \mathrm{~S}$ yang tinggi. Faktor tersebut umumnya terjadi karena sumber air atau sumur dibuat terlalu dekat dengan saptictank atau tempat pembuangan kotoran.

Tabel 4. Pemeriksaan Warna Air Bersih Gerbong Kereta Api Kelas Ekonomi Dan Eksekutif

\begin{tabular}{llllll}
\hline No & Kereta Api & Kelas & $\begin{array}{l}\text { Jumlah toilet } \\
\text { per gerbong }\end{array}$ & Hasil (\%) & Keterangan \\
\hline 1. & Serayı & Ekonomi & 2 & $<100 \%$ & Tidak Baik \\
\hline 2. & Kamandaka & Ekselutuif & 1 & $100 \%$ & Baik \\
\hline
\end{tabular}

Pemeriksaan warna pada air bersih gerbong kereta api ini dilakukan dengan alat spektrofotometri. Selain sebagai estetika, warna air juga dapat digunakan sebagai indikator pencemaran air. warna air sebaiknya jernih, apabila berubah warna dapat indikasikan terjadinya pencemaran air. berdasarkan pengukuran yang telah dilaksanakan pada air bersih di gerbong kereta api kelas ekonomi dan eksekutif , keduanya memenuhi standar baku mutu warna air bersih Permenkes 32 Tahun 2017 yaitu sebesar $50 \mathrm{TCU}$, dimana pada kereta api kelas ekonomi didapati hasil sebesar 10,7TCU dan kereta api kelas eksekutif sebesar 5,5 TCU.

Tabel 5. Pemeriksaan Rasa Air Pada Gerbong Kereta Api Dengan Metode Organoleptik

\begin{tabular}{llcl}
\hline No & Kereta Api & Panelis & Hasil \\
\hline 1. & Ekonomi & 1 & Tidak berasa \\
\hline & & 2 & Tidak berasa \\
\hline & & 3 & Tidak berasa \\
\hline 2, & Eksekutif & 1 & Tidak berasa \\
\hline & & 2 & Tidak berasa \\
\hline & & 3 & Tidak berasa \\
\hline
\end{tabular}


Air bersih biasanya tidak memberi rasa/tawar. Air yang tidak tawar dapat menunjukkan kehadiran berbagai zat yang dapat membahayakan kesehatan. Rasa logam/amis, rasa pahit, asin dan sebagainya. Efeknya tergantung pula pada penyebab timbulnya rasa tersebut.

Tabel 6. Pemeriksaan Kekeruhan Air Bersih Gerbong Kereta Api Kelas Ekonomi dan Eksekutif

\begin{tabular}{llllll}
\hline No & Kereta Api & Kelas & Hasil & Syarat & Keterangan \\
\hline 1. & Serayu & Ekonomi & $<5 \mathrm{NTU}$ & $<25 \mathrm{NTU}$ & $\begin{array}{l}\text { Memenuhi } \\
\text { syarat }\end{array}$ \\
\hline 2. & Kamandaka & Eksekutifi & $<5 \mathrm{NTU}$ & $<25 \mathrm{NTU}$ & $\begin{array}{l}\text { Memenuhi } \\
\text { syarat }\end{array}$ \\
& & & &
\end{tabular}

Berdasarkan pengukuran air bersih pada kedua gerbong didapati hasil keduanya memenuhi syarat yaitu <5NTU dimana dalam Peraturan Menteri Kesehatan Nomor 32 Tahun 2017 tentang Standar Baku Kesehatan Lingkungan Dan Persyaratan Kesehatan Air Untuk Keperluan Higiene Sanitasi, Kolam Renang, Solus Per Aqua, dan Pemandian Umum disebutkan bahwa standar baku mutu kekeruhan untuk air hygiene sanitsi adalah sebar 25NTU.

Menurut Prof. Dr Juli Soemirat Slamet, kekeruhan air disebabkan oleh zat padat yang tersuspensi, baik yang bersifat anorganik maupun organik. Zat anorganik biasanya berasal dari lapukan batuan dan logam, sedangkan yang organik dapat berasal dari lapukan tanaman atau hewan. Buangan industri juga merupakan sumber kekeruhan. Zat organik dapat menjadi makanan bakteri, sehingga mendukung perkembangbiakannya. Bakteri ini juga merupakan zat organik tersuspensi, sehingga pertambahanya akan menambah pula kekeruhan air. air yang keruh sulit didesinfeksi, karena mikroba terlindung oleh zat tersuspensi tersebut. Hal ini tentu berbahaya bagi kesehatan, bila mikroba itu patogen.

Tabel 7. Pemeriksaan TDS air bersih gerbong Kereta Api Kelas ekonomi dan eksekutif

\begin{tabular}{llllll}
\hline No & Kereta Api & Kelas & Hasil & Syarat & Keterangan \\
\hline 1. & Serayu & Ekonomi & $258 \mathrm{mgl}$ & $1000 \mathrm{mg} /$ & $\begin{array}{l}\text { Memenuhi } \\
\text { syarat }\end{array}$ \\
\hline 2. & Kamandaka & Eksekutif & $353 \mathrm{mgl}$ & $1000 \mathrm{mgll}$ & $\begin{array}{l}\text { Memenuhi } \\
\text { syarat }\end{array}$ \\
\hline
\end{tabular}

Berdasarkan hasil pengukuran TDS air bersih pada gerbong kereta api, diketahui hasil TDs kereta api kelas ekonomi sebesar
$258 \mathrm{mg} / \mathrm{l}$ dan kereta api kelas eksekutif sebesar $353 \mathrm{mg} / \mathrm{l}$. Menurut WHO (World Health Organization), kandungan mineral dalam air tidak akan berpengaruh terhadap kesehatan selama air masih dikategorikan tawar. Meski begitu, tetap diberikam standar kualitas air bersih sebesar $1000 \mathrm{mg} / \mathrm{l}$ menurut Peraturan Menteri Kesehatan Nomor 32 Tahun 2017 tentang Standar Baku Kesehatan Lingkungan Dan Persyaratan Kesehatan Air Untuk Keperluan Higiene Sanitasi, Kolam Renang, Solus Per Aqua, dan Pemandian Umum.

Tabel 8. Pemeriksaan suhu air bersih gerbong Kereta Api Kelas ekonomi dan eksekutif

\begin{tabular}{|c|c|c|c|c|c|c|}
\hline No & Kereta Api & Kelas & Hasil & $\begin{array}{l}\text { Suhu } \\
\text { ruangan }\end{array}$ & Syarat & Keterangan \\
\hline 1. & Serayu & Ekonomi & $29^{\circ} \mathrm{C}$ & $27,6^{\circ} \mathrm{C}$ & $\begin{array}{l} \pm 3^{\circ} \mathrm{C} \\
\text { suhu } \\
\text { ruangan }\end{array}$ & $\begin{array}{l}\text { Memenuhi } \\
\text { syarat }\end{array}$ \\
\hline 2. & Kamandaka & Eksekutif & $24^{\circ} \mathrm{C}$ & $26,3^{\circ} \mathrm{C}$ & $\begin{array}{l} \pm 3^{\circ} \mathrm{C} \\
\text { suhu } \\
\text { ruangan }\end{array}$ & $\begin{array}{l}\text { Memenuhi } \\
\text { syarat }\end{array}$ \\
\hline
\end{tabular}

Suhu air sebaiknya sejuk atau tidak panas agar tidak terjadi pelarutan zat kimia yang ada pada saluan/pipa yang dapat membahayakan kesehatan, menghambat reaksi-reaksi biokimia didalam saluran/p ipa, mikroorganisme patogen tidak mudah berkembang biak. Menurut Peraturan Menteri Kesehatan Nomor 32 Tahun 2017 tentang Standar Baku Kesehatan Lingkungan Dan Persyaratan Kesehatan Air Untuk Keperluan Higiene Sanitasi, Kolam Renang, Solus Per Aqua, dan Pemandian Umum, standar baku mutu air bersih untuk keperluan hygiene sanitasi perorangan yaitu sebesar $\pm 3^{\circ} \mathrm{C}$ dari suhu ruangan. Dalam pemeriksaan air bersih pada gerbong keduanya telah memenuhi standar yang berlaku (Tabel 8)

Suhu juga berpengaruh terhadap pertumbuhan mikroba. Mirkoba memiliki standar suhu yang berbeda-beda untuk pertumbuhana. Apabila suhu air dalam sesuai standar untuk pertumbuhan mikroba hingga optimum, maka pencemaran air akan semakin besar apabila terdapat mikroba patogen.

6) Kualitas Kimia Air Bersih

Tabel 9. Pemeriksaan $\mathrm{pH}$ Air Bersih Gerbong Kereta Api Kelas ekonomi dan eksekutif

\begin{tabular}{llllll}
\hline No & Kereta Api & Kelas & Hasil & Syarat & Keterangan $\mid$ \\
\hline 1. & Serayu & Ekonomi & 8 & $6-8,5$ & Memenuhi syarat \\
\hline 2. & Kamandaka & Eksekutif & 8,4 & $6-8,5$ & Memenuhi syarat
\end{tabular}


Berdasarkan dari pemeriksaan $\mathrm{pH}$ air bersih pada kereta api ekonomi dan kereta api eksekutif didapati hasil yang memenuhin standar, yaitu untuk kereta api ekonomi sebesar 8 dan kereta api dan kereta api kelas eksekutif sebesar 8,4. Menurut Hastuti (2009) $\mathrm{pH}$ merupakan salah satu faktor yang mempengaruhi perkembangbiakan mikroba. Beberapa faktor yang dapat mempengaruhi pertumbuhan bakteri antara lain : suhu, kelembaban, cahaya, pH, dan lainya. Apabila faktor tersebut memenuhi syarat, sehingga optimum untuk pertumbuhan bakteri, maka bakteri dapat tumbuh dan berkembang biak.

7) Kualitas Mikrobiologi Air Bersih

Tabel 10. Pemeriksaan Total Coliform Air Bersih Gerbong Kereta Api

\begin{tabular}{lllcll}
\hline No & Kereta Api & Kelas & Hasil & Syarat & Keterangan \\
\hline 1. & Serayu & Ekonomi & 41 CFU/100ml & 50 & Memenuhi syarat \\
& & & & CFU/100ml & \\
\hline 2. & Kamandaka & Ekselkutif & 23CFU/100ml & $\begin{array}{l}50 \\
\text { CFU/100ml }\end{array}$ & Memenuhi syarat \\
& & & & & \\
\hline
\end{tabular}

Diketahui hasil Total Coliform pada air bersih gerbong kereta api kelas ekonomi ini sebesar $41 \mathrm{CFU} / 100 \mathrm{ml}$. Berdasarkan Peraturan Menteri Kesehatan Nomor 32 Tahun 2017 tentang Standar Baku Kesehatan Lingkungan Dan Persyaratan Kesehatan Air Untuk Keperluan Higiene Sanitasi, Kolam Renang, Solus Per Aqua, dan Pemandian Umum baku mutu Total Coliform air bersih untuk keperluan higiene sanitasi sebesar $50 \mathrm{CFU} / 100 \mathrm{ml}$. Dengan hasil tersebut berarti air bersih tersebut memenuhi syarat.

Diketahui hasil Total Coliform pada air bersih gerbong kereta api kelas ekonomi ini sebesar $23 \mathrm{CFU} / 100 \mathrm{ml}$. Berdasarkan Peraturan Menteri Kesehatan Nomor 32 Tahun 2017 tentang Standar Baku Kesehatan Lingkungan Dan Persyaratan Kesehatan Air Untuk Keperluan Higiene Sanitasi, Kolam Renang, Solus Per Aqua, dan Pemandian Umum baku mutu Total Coliform air bersih untuk keperluan higiene sanitasi sebesar $50 \mathrm{CFU} / 100 \mathrm{ml}$. Dengan hasil tersebut berarti air bersih tersebut memenuhi syarat.

Bakteri Coliform adalah golongan mikroorganisme yang lazim digunakan sebagai indikator, dimana bakteri ini dapat menjadi sinyal untuk menentukan suatu sumber air yang terkontamunasi oleh patogen atau tidak (Pracoyo,2006). Maka dari itu, terdapat standar baku mutu untuk bakteri coliform di air bersih. Beberapa patogen yang telah dikenal sejak beberapa dekade lalu adalah Vibrio Cholerae, Salmonella thyphi, virus hepatitis a.

8) Kuantitas Air Bersih Gerbong Kereta Api

Tabel 11. Kebutuhan air bersih gerbong Kereta Api Kelas ekonomi dan eksekutif

\begin{tabular}{|c|c|c|c|c|c|c|c|}
\hline $\mathrm{N}_{0}$ & Kereta Api & Kelas & $\begin{array}{l}\text { Kapasitas } \\
\text { Resemvir }\end{array}$ & $\begin{array}{l}\text { Jumlah } \\
\text { Irsertoir }\end{array}$ & $\begin{array}{l}\text { Jumlah } \\
\text { lursi }\end{array}$ & Syarat & Keterangan \\
\hline 1. & Serayu & Ekonomi & 5001iter & 2 & 106 & 6ttorang han ${ }^{*}$ & $\begin{array}{l}\text { Tidak } \\
\text { memenubi } \\
\text { syarat }\end{array}$ \\
\hline 2. & Kamandaka & Elselutif & 1000ititer & 1 & 50 & 6ttoranghan ${ }^{*}$ & $\begin{array}{l}\text { Memenuhi } \\
\text { syarat }\end{array}$ \\
\hline
\end{tabular}

Kuantitas air pada gerbong ini tidak memenuhi syarat. dimana estimasi penggunaan air bersih per orang adalah 6 liter, maka seharusnya kapasitas air dapat menampung sebsar 1272 liter. Apabila reservoir hanya menampung air sebesar 1000 liter maka hanya dapat mencukupi sebesar 166 penumpang saja, yang seharusnya mencukupi sebesar 212 penumpang.

Berdasarkan perhitungan tersebut kuantitas air pada gerbong ini memenuhi syarat, dimana estimasi penggunaan air bersih per orang adalah 6 liter dengan penumpang sebanyak 100 orang sehingga kebutuhan total air bersih dalam 1 gerbong sebesar 600 liter. Kapasitas reservoir ini sebesar 1000 liter, sehingga menyisakan air sebesar 400 liter. Reservoir yang berkapasitas 1000liter ini dapat mencukupi penggunaan air bersih sebesar 166 orang, dimana dalam satu gerbong hanya terdapat 100 orang, maka kapasitas air bersih ini masih dapat mencukupi sekitar 66 orang.

9) Standar Minimum Pelayanan Minimum Kereta Api

Tabel 12. Standar Pelayanan Minimum Gerbong Kereta api

\begin{tabular}{llcll}
\hline No & Kereta Api & Kelas & Hasil $(\%)$ & Keterangan \\
\hline 1. & Serayu & Ekonomi & $100 \%$ & Memenuhi syarat \\
\hline 2. & Kamandaka & Eksekutif & $100 \%$ & Memenuhi syarat \\
\hline & \multicolumn{2}{c}{ Berdasarkan } & hasil & observasi,
\end{tabular}

diketahui kedua kereta api telah memenuhi persyaratan sesuai PM 48 Tahun 2015, yaitu terdapat apar, katup darurat, alat pemecah kaca dan kotak P3K sebagai aspek keselamatan. Kemudian pada aspek keamanan terdapat cctv pada rangkaian kereta dan petugas ketertiban dalam kereta dan juga terdapat lampu penerangan di setiap kereta. Pada aspek kenyamanan terdapat kursi penumpang, AC sebagai sirkulasi udara, dan gerbong restorasi. Setiap 
kereta disediakan kursi prioritas untuk penunjang disabilitas.

\section{Kesimpulan}

Berdasarkan hasil penelitian dan pembahasan yang telah dilakukan diketahui sumber air bersih yang digunakan untuk pengisian air pada gerbong kereta api bersumber dari sumur artesis dan pendistribusian air bersih yang kurang baik, karena tidak ada pemeliharaan secara rutin untuk sarana-sarana air bersih. Keadaan sarana air bersih meliputi sanitasi reservoir pada kereta api kelas ekonomi dan eksekutif tidak memenuhi syarat dikarenakan pada reservoir sudah berkarat dan mengelupas dan tidak dilakukan pengurasan dan pembersihan, kemudian keadaan sanitasi perpipaan air bersih kereta api keduanya telah memenuhi syarat, dan keadaan sanitasi toilet pada kereta api kelas eksekutif telah memenuhi syarat, namun pada kereta api kelas ekonomi tidak memenui syarat dikarenakan keadaan toilet berbau urine.

Kualitas fisik air bersih gerbong kereta api yang meliputi bau, rasa, warna, TDS, kekeruhan dan suhu kedua kelas kereta memenuhi syarat sesuai dengan baku mutu Permenkes 32 Tahun 2017. Kualitas kimia air yang meliputi derajat keasaman airbersih gerbong kereta api baik kelas ekonomi dan eksekutif telah memenuhi standar baku mutu Permenkes 32 Tahun 2017. Kualitas mikrobiologi (total coliform) air bersih gerbong kereta api sudah memenuhi standar, dengan hasil $41 \mathrm{CFU} / 100 \mathrm{ml}$ untuk kereta api kelas ekonomi dan 23 CFU/100ml untuk kereta api kelas eksekutif, dengan persyaratan standar baku mutu air bersih untuk higiene sanitasi pada Permenkes 32 Tahun 2017 yaitu sebesar 50 CFU/100ml.

Kuantitas air bersih pada gerbong kereta api kelas ekonomi tidak memenuhi kebutuhan dengan syarat kebutuhan air perharinya sebesar 1270 liter dengan kapasitas reservoir 1000liter, sedangkan pada gerbong kereta api kelas eksekutif memenuhi syarat yang memiliki reservoir sebesar 1000liter dengan kebutuhan air bersih perharinya 600 liter, sehingga memenuhi syarat kebutuhan perharinya. Standar pelayanan minimum dalam kereta api memenuhi syarat dengan skor $100 \%$.

\section{Saran}

1. Bagi PT. Kereta Api Indonesia

a. Melakukan pemeliharaan terhadap reservoir, dengan melakukan pengurasan, pembersihan, dan pembaharuan konstruksi reservoir

b. Memperhatikan kebersihan toilet dan gerbong untuk menghindari adanya vektor yang bersarang.

c. Memelihara jaringan-jaringan perpipaan air bersih bermula dari sumber hingga pengguna

2. Bagi masyarakat / penumpang kereta api

a. Senantiasa menjaga kebersihan toilet kereta api.

b. Menggunakan air bersih pada gerbong kereta api dengan tidak boros.

\section{Daftar Pustaka}

Abbas, Salim, 2000, Manajemen Transportasi, Jakarta, Ghalia Indonesia

Ayu, Dewa Nyoman Sriastuti, 2015, Kereta Api Pilihan Utama Sebagai Moda Alternatif Angkutan Umum Massal, Bali, Paduraksa.

Departemen Kesehatan RI Direktorat Penyehatan Air (DITJEN PPM \& PLP),1997, Pedoman Studi Kualitas Air, Jakarta :DITJEN PPM \& PLP

Djasio Sanropi dkk, 1983, Penyediaan Air Bersih, Jakarta, PT. Rineka Cipta

, 1998, Pedoman Penyehatan Air Bagi Petugas Sanitasi Puskesmas, Jakarta, : DITJEN PPM \& PLP

Effendi, hefni, 2012, Proses Pengolahan Air Bersih Pada PDAM Padang. Avaible from: http://ejournal.itp.ac.id. (Accesed : 24 November 2018)
2003. Telaah Kualitas Air Bagi Pengelolaan Sumber Daya dan Lingkungan Perairan. Yogyakarta: Kanisius

Ferdiaz, srikandi, 1992, Mikrobiologi Pangan, Jakarta, : PT. Gramedia Pustaka Utama

Government of New Zaeland, 2007, Freshwater, Acaible from : http://mfe.govt.nz (Accessed 11 Desember 2018)

Karsidi, 1999, Hubungan antara Tingkat Pendidikan dan Pendapatan dengan Penggunaan Air Sungai oleh Penduduk di sekitar Sungai Kali Jajar Demak, Semarang : Skripsi

Peraturan Pemerintah No.82 Tahun 2001 tentang Pengelolaan Kualitas Air dan Pengendalian Pencemaran Air

Sanropie, Djasio et. Al., 1983, Penyediaan Air Bersih, Jakarta, : Pusat Pendidikan dan Pelatihan Pegawai Departemen Kesehatan RI 


\section{BUTETIN \\ KESLIN GMAS}

Thoblis sertama kall April 1982 Buletin Kesehatan Lingkungan Masyarakat

Saparuddin, 2010, Pemanfaatan Air Tanah Dangkal Sebagai Sumber Air Bersih di Kampus Bumi Bahari Palu. Available from : http://jurnal.untad.ac.id (Accessed : 8 Desember 2018)

Skinner, B and Shaw, R, 2010, Household Water Treatment. Avaible from: http://lboro.ac.uk (Accessed: 25 November 2018)

Soemirat, Juli Slamet, 2009, Kesehatan Lingkungan , Bandung, Gadjah Mada University Press
Soufyan dan Morimura, 1991, Perancangan dan Pemeliharaan Sistem Plambing, Jakarta, PT. Pradnya Paramita.

Soetrisno Totok dkk, 2010, Teknologi Penyediaan Air Bersih, Jakarta, Rineka Cipta

Suparmin, 2011, Teori dan Praktik Pengolahan Air Minum, Purwokerto, Yayasan Sanitarian Banyumas 